Proc. Estonian Acad. Sci. Biol. Ecol., 2002, 51, 4, 277-293

\title{
Feeding of herring in the Gulf of Finland in the 1970s-90s
}

\author{
Ain Lankov ${ }^{\mathrm{a}^{*}, \mathrm{~b}}$ and Henn Kukk $\mathrm{K}^{\mathrm{b}, \mathrm{c}}$ \\ a Pärnu Field Station, Estonian Marine Institute, Vana-Sauga 28, 80031 Pärnu, Estonia \\ b Tallinn Pedagogical University, Narva mnt. 25, 10120 Tallinn, Estonia; henn@tpu.ee \\ ${ }^{c}$ Estonian Marine Institute, Marja 4d, 10617 Tallinn, Estonia
}

Received 20 December 2001, in revised form 15 May 2002

\begin{abstract}
In the 1980s-90s the feeding of pelagic fishes, including Baltic herring, changed due to altered hydrological conditions. The feeding intensity of herring decreased and its food spectrum shifted towards the energetically less valuable zooplankton. As a result, the mean body weight of herring decreased significantly. In the second half of the 1990s the process retarded and the weight of herring stabilized at the level of about $10 \mathrm{~g}$ lower than at the beginning of the 1970s. The annual food consumption of herring in the Gulf of Finland was the highest at the end of the 1980s, reaching $130 \mathrm{~g} \mathrm{~m}^{-2}$ (wwt). At the end of the 1990s it was $65-70 \mathrm{~g} \mathrm{~m}^{-2}$ (wwt). In the 1970s and in first half of the $1980 \mathrm{~s}$ the annual metabolic rates constituted from 74.4 to $76.5 \%$ and the growth rate from 1.6 to $3.5 \%$ of the annual ration. In the second half of the 1980s and in the 1990s the amplitudes of metabolic and growth rates were restricted compared to the previous period (74.7-75.9\% and 2.3$2.9 \%$, respectively). In the 1990 s the energy released for spawning rose, forming from 2.0 to $2.7 \%$ of the ration.
\end{abstract}

Key words: Baltic herring, annual consumption, food composition, feeding spectrum.

\section{INTRODUCTION}

Baltic herring (Clupea harengus membras L.) and Baltic sprat (Sprattus sprattus balticus Schn.) form an important part of the pelagic ecosystem of the Baltic Sea. They constitute the main part of the biomass of the fish feeding on zooplankton, mysids (Mysidae), amphipods (Amphipoda), and several other pelagic and nektobenthic organisms. Herring, sprat, and cod are the fish species responsible for the top-down control in the Baltic pelagic ecosystem (Rudstam et al., 1994). On this basis, gadoid or clupeoid dominated fish ecosystems are distinguished. Depending on hydrological and biological conditions and fishing mortality, these may change from one into the other.

* Corresponding author, ain_parnu@ @hotmail.com 
In the 1980s-90s the stocks of herring, sprat, and cod varied greatly in the Baltic Sea, including in the Gulf of Finland (Fig. 1). From the beginning of the 1980s to the early 1990s, both the abundance and biomass of eastern Baltic cod decreased and its area reduced. Thus, in the 1990s, the distribution of cod no longer extended into the northern Baltic Sea and the Gulf of Finland. In the Baltic Proper the biomass of herring started to decline in the early 1980s and it stabilized at the end of the 1990s. Also, changes in sprat biomass were very obvious in the Baltic. Consequently, important changes occurred in the food web structure and energy balance in the Baltic Sea.

The Gulf of Finland is the easternmost part of the Baltic Sea. Its hydrological conditions are variable and depend on the distance from the Baltic Proper. Significant differences exist between the western and eastern parts of the Gulf of Finland. The $26^{\circ} \mathrm{E}$ meridian, at which a heterohaline water layer occurs, serves as the conditional boundary between these parts (Ojaveer \& Veldre, 1976; Ojaveer \& Elken, 1997). The salinity of surface water decreases from 6-7 psu at the entrance to the Gulf to 5 psu in Narva Bay and 2-3 psu in Luga-Koporje Bay (Perttilä et al., 1980; Møller \& Hansen, 1994).

The long-term (1970-99) mean annual temperature in the surface layer was $0.2^{\circ} \mathrm{C}$ in February and $17.3^{\circ} \mathrm{C}$ in August (data of the Estonian Meteorological and Hydrological Institute, EMHI). During the summer period, the shallower eastern part of the Gulf warms up faster and the thermocline there is located deeper. In August 1961-90, the mean temperature in the 0-20 m layer was $13.7^{\circ} \mathrm{C}$ in the western and $14.6^{\circ} \mathrm{C}$ in the eastern part of the Gulf (Lumberg \& Ojaveer, 1991). Figure 2 shows changes in the mean temperature of the surface layer and in

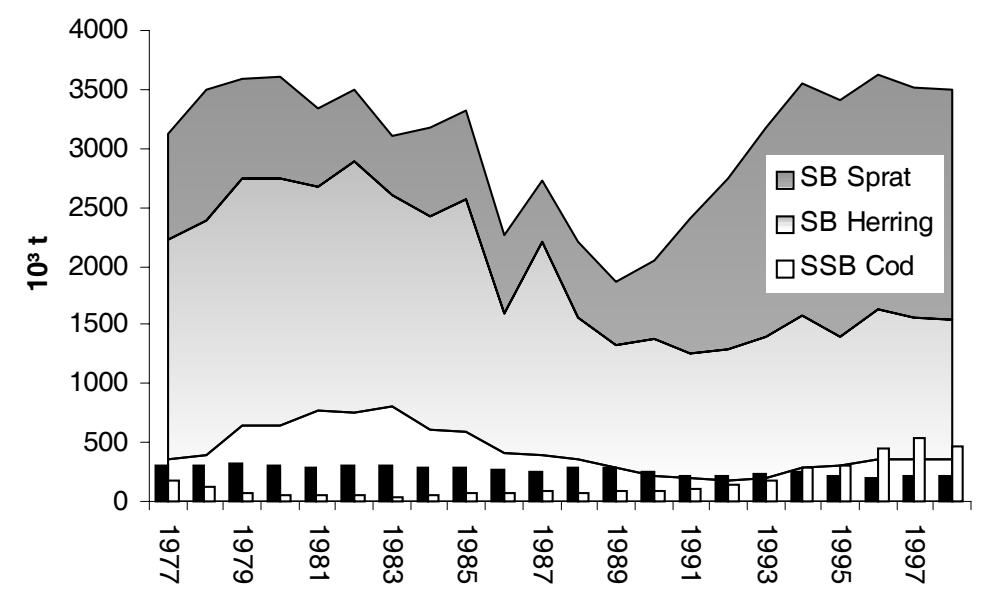

Fig. 1. Total stock biomass (SB) of Baltic herring and sprat and spawning stock biomass (SSB) of cod in the Baltic Sea (ICES Sub-divisions 25-29+32, 22-32, and 25-32, respectively) in 1977-98. Below: black bars - herring catch (Sub-divisions 25-29+32), empty bars - sprat catch (Sub-divisions 22-32) (Anon., 1995, 1997, 1999). 


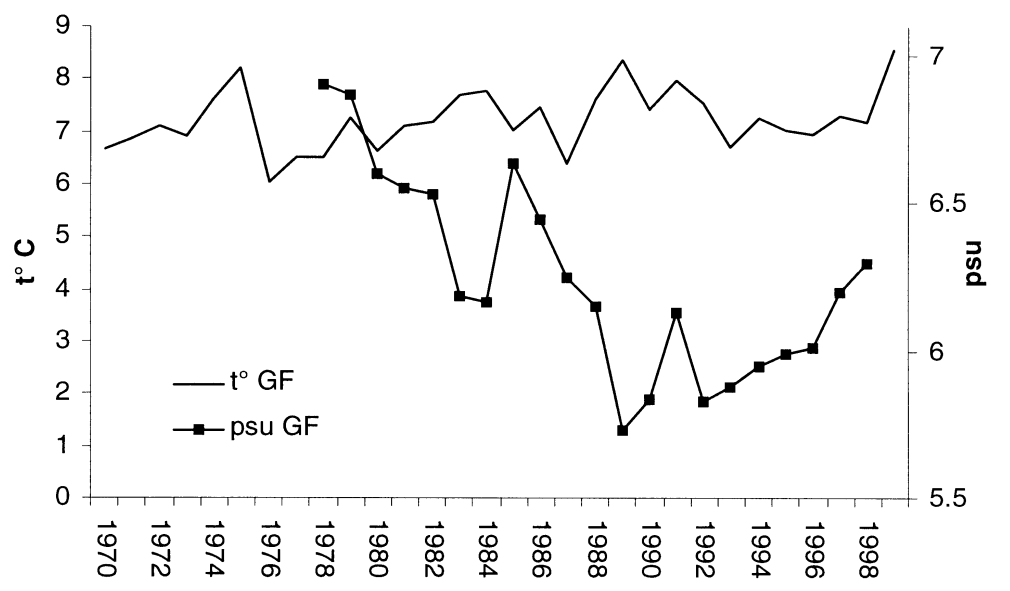

Fig. 2. Mean temperature of the surface layer and salinity in the $0-60 \mathrm{~m}$ layer (at $59^{\circ} 51^{\prime} \mathrm{N}$, $24^{\circ} 50^{\prime} \mathrm{E}$ ) in the Gulf of Finland (based on HELCOM, 1996; and data from EMHI).

the mean salinity in the 0-60 m layer. As can be seen, there was a slight increase in the mean temperature, while the mean salinity clearly decreased from the end of the 1970s to the end of the 1980s. However, since 1993 there is an obvious rise in salinity, which is probably due to a major inflow of salted water from the North Sea that year (Håkansson et al., 1993). As in the winter period the air temperature above the eastern part of the Gulf is considerably lower and the water cools down faster, the length of the ice-cover period increases from west to east. The ice-cover usually lasts for 50 days on the north coast of Hiiumaa Island, for 70 days in the area of Naissaar Island, for 90 days in Kunda Bay, and for 110 days in Narva Bay. The duration of the ice-cover is controlled by a permanent current running from west to east at the southern coast of the Gulf of Finland and from east to west at the northern coast (Astok \& Mardiste, 1995).

\section{MATERIAL AND METHODS}

Adult Baltic herring were collected from 30-min hauls by a pelagic trawl (mesh size 5-10 mm). From one catch $20-50$ specimens were taken and fixed in $4 \%$ formaldehyde solution.

A total of about 8900 stomach contents of herring from the Gulf of Finland (Fig. 3) were analysed in 1982, 1985-94, and 1999. Table 1 shows the distribution of samples by time and length groups of herring. The total length and weight of herring were measured. The wet weight of the whole stomach content was weighed using torsion scales WTW. Larger food organisms (Mysidae, Amphipoda, Saduria, fish), were weighed and counted individually. The remaining part (zooplankton) was diluted in water and counted in the Bogorov chamber like an ordinary plankton sample. 


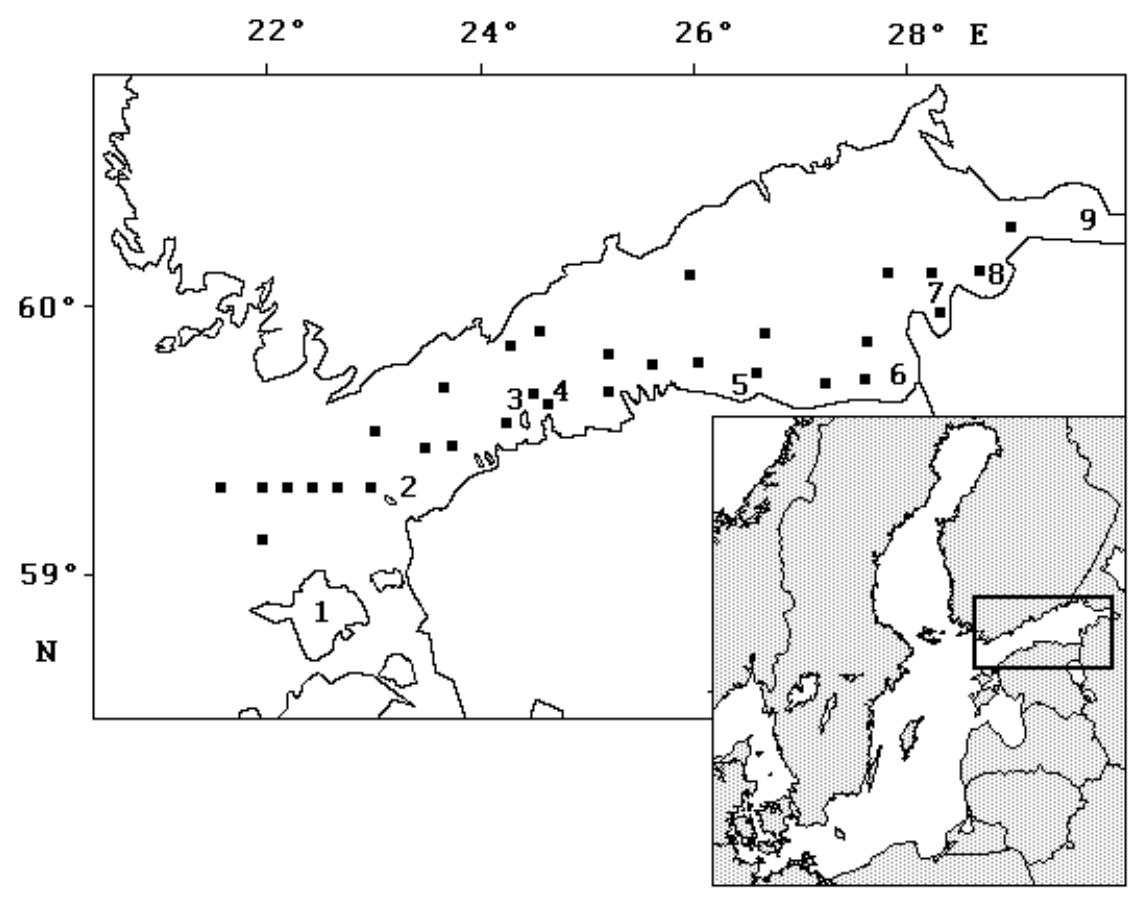

Fig. 3. Location of sampling places in the Gulf of Finland in 1982, 1985-94, and 1999 (1 - Hiiumaa Island; 2 - Osmussaar Island; 3 - Naissaar Island; 4 - Keri Island; 5 - Kunda Bay; 6 - Narva Bay; 7 - Luga Bay; 8 - Koporje Bay; 9 - Neva Bay).

The feeding of herring was described based on the proportion of empty stomachs (\%) and the food composition or feeding spectrum (the share of food organisms by the wet weight $\%$ and abundance $\%$ ). Literature data on the energy consumption of sea fish and the Winberg method (Winberg, 1956, 1966, 1970; Green, 1978; Ricker, 1973; Aneer, 1975a, 1979; Chekunova \& Naumov, 1977; Chekunova, 1979; Melnichuk, 1980; Arrhenius \& Hansson, 1993, 1995; Raid \& Lankov, 1995) were applied for the determination of the energy budget.

The annual ration $(C)$ for Baltic herring can be expressed by the equation:

$$
C=R+P+P_{q}+F(\mathrm{~kJ}),
$$

where $R$ denotes the energy used in metabolism, $P$ is the energy used for annual growth, $P_{q}$ is the energy released for spawning, and $F$ stands for energy losses (faeces).

As herring's feeding intensity is very low during the spawning and wintering periods, the average duration of its feeding period in the Gulf of Finland is approximately 270 days (Ostov, 1971; Smirnov, 1971).

Bioenergetic processes in fish are strongly affected by temperature (Szypuła \& Załachowski, 1984). The annual metabolic rate $(R)$ of Baltic herring can be 
Table 1. Number of fish analysed for feeding investigations of the Baltic herring

\begin{tabular}{|c|c|c|c|c|c|c|c|}
\hline \multirow{2}{*}{ Year } & \multirow{2}{*}{ Quarter } & \multicolumn{5}{|c|}{ Length group $(L, \mathrm{~cm})$} & \multirow{2}{*}{ Total } \\
\hline & & $<10$ & $10-13.9$ & $10-17.9$ & $18-21.9$ & $>22$ & \\
\hline \multirow[t]{2}{*}{1982} & II & 0 & 13 & 129 & 40 & 18 & 200 \\
\hline & IV & 11 & 57 & 120 & 25 & 7 & 220 \\
\hline \multirow[t]{2}{*}{1985} & II & 111 & 246 & 72 & 22 & 4 & 455 \\
\hline & IV & 1 & 94 & 327 & 133 & 45 & 600 \\
\hline \multirow[t]{2}{*}{1986} & II & 0 & 12 & 152 & 207 & 70 & 441 \\
\hline & IV & 9 & 70 & 316 & 275 & 65 & 735 \\
\hline \multirow[t]{3}{*}{1987} & II & 21 & 41 & 85 & 100 & 53 & 300 \\
\hline & III & 224 & 414 & 805 & 89 & 0 & 1532 \\
\hline & IV & 35 & 463 & 193 & 72 & 7 & 770 \\
\hline \multirow[t]{3}{*}{1988} & II & 12 & 32 & 84 & 51 & 9 & 188 \\
\hline & III & 0 & 300 & 435 & 0 & 0 & 735 \\
\hline & IV & 0 & 12 & 78 & 42 & 28 & 160 \\
\hline \multirow[t]{3}{*}{1989} & II & 5 & 12 & 97 & 61 & 45 & 220 \\
\hline & III & 0 & 84 & 316 & 0 & 0 & 400 \\
\hline & IV & 59 & 39 & 42 & 16 & 3 & 159 \\
\hline \multirow[t]{2}{*}{1990} & II & 63 & 142 & 494 & 45 & 14 & 758 \\
\hline & IV & 0 & 41 & 100 & 13 & 1 & 155 \\
\hline \multirow[t]{2}{*}{1991} & II & 25 & 26 & 72 & 25 & 12 & 160 \\
\hline & IV & 8 & 3 & 33 & 10 & 0 & 54 \\
\hline 1992 & IV & 25 & 108 & 58 & 9 & 1 & 201 \\
\hline 1993 & IV & 56 & 63 & 61 & 0 & 0 & 180 \\
\hline 1994 & IV & 10 & 36 & 133 & 1 & 0 & 180 \\
\hline 1999 & IV & 24 & 46 & 50 & 0 & 0 & 120 \\
\hline Total & & & & & & & 8923 \\
\hline
\end{tabular}

expressed using Krogh's temperature correction coefficient $q$ calculated on the basis of the mean temperature during the main feeding period of herring (AprilDecember). During 1970-98, the mean annual temperature in the 0-60 m layer in the Gulf of Finland varied in the range $4.55-7.27^{\circ} \mathrm{C}$ and the calculated value of metabolism $(R)$ in herring ranged from $27.6 W^{0.978}$ to $39.4 W^{0.978} \mathrm{~kJ} \mathrm{yr}^{-1}$ ( $W$ denotes body weight in grams).

The energy used annually for the growth of Baltic herring is calculated as follows:

$$
P=5.53 \Delta W\left(\mathrm{~kJ} \mathrm{yr}^{-1}\right) .
$$

The energy released at the spawning of herring was calculated applying the data on the fecundity and the mean weight of gonads and of the body (Rannak, 1970; Lasker, 1973; Green, 1978; Raid \& Lankov, 1995). The energy released at the spawning of herring can be expressed as:

$$
P_{q}=2.76(0.225 W+4.39)\left(\mathrm{kJ} \mathrm{yr}^{-1}\right) .
$$

The energy losses through faecal material and excretion ( $F$ in Eq. (1)) make up about $20 \%$ for the fish feeding on animal prey (Melnichuk, 1980). 


\section{RESULTS AND DISCUSSION Feeding of herring in the Gulf of Finland}

Feeding of Baltic herring has been described by many authors (e.g., Jespersen, 1936; Popiel, 1951; Sushkina, 1954; Bityukov, 1961; Sjöblom, 1961; Aneer, 1975a, b, 1980; Trauberga, 1979; Kostrichkina \& Starodub, 1980; Lankov, 1986; Ojaveer, 1988; Flinkman et al., 1992; Rudstam et al., 1992; Arrhenius \& Hansson, 1993; Raid \& Lankov, 1995; Davidyuk, 1996; Szypuła et al., 1997; Flinkman et al., 1998; Flinkman, 1999; Feldman et al., 2001).

In the Baltic Sea herring feeds on marine boreal, freshwater, and relict species. The proportion of relicts is the highest in bays (Ojaveer, 1988). The feeding of Baltic herring has a clear selective character, i.e. the proportions of zooplankton, mysids, and amphipods vary in its ration (Aneer, 1980; Arrhenius \& Hansson, 1993; Raid \& Lankov, 1995; Flinkman, 1999).

Feeding intensity varies with years; it depends on hydrological factors (temperature, salinity, position of the thermocline) as well as on the composition, abundance and distribution of food organisms. However, it is the water temperature that controls the feeding intensity determining it through the digestion rate (Szypuła \& Załachowski, 1984).

\section{Food composition}

In the western Gulf of Finland Baltic herring feeds prevailingly on copepods of marine origin, such as Pseudocalanus elongatus, Temora longicornis, and Centropages hamatus. Throughout the whole gulf the main prey items of herring are the brackish-water Eurytemora affinis and Acartia spp. The cold-water species Limnocalanus grimaldii was found in the food of larger herring in deeper water layers. The fresh-water species Mesocyclops leuckarti was an abundant prey for herring in Narva Bay and east of it. Cladocerans were widely taken. The euryhaline species Bosmina coregoni maritima, Pleopsis polyphemoides, Podon intermedius, and Evadne nordmanni were among herring prey all over the Gulf of Finland, but their share was the highest in the eastern part. In Luga Bay the freshwater Ceriodaphnia sp. and Daphnia sp. appeared in the diet of herring. The above-described differences manifest themselves especially clearly in the summer period.

In the ration of adult herring, nektobenthic organisms (Mysidae, Amphipoda), larvae, young fish, and benthos become increasingly more important. A small part of individuals - the so-called giant herring - pass faster on predation (on goby, smelt, sprat) and their growth accelerates. In the case of giant herring, cannibalism was sometimes observed in the eastern part of the Gulf of Finland.

Compared to the other parts of the Baltic Sea, the food ration of herring in the Gulf of Finland is richer in mysids and amphipods, although since the end of the 1980s the proportion of these food objects has decreased, particularly in the spring and summer periods (Raid \& Lankov, 1991, 1995; Lankov \& Raid, 1997). 


\section{Seasonal dynamics in feeding}

In the Gulf of Finland seasonal changes are very well expressed in herring feeding. In March-April herring migrate from wintering sites towards spawning grounds at the coast and in bays. During this season, the distribution of herring is closely related to the abundance of food organisms preferred by one or other age group in the water layer. The generation hatched in the previous year remains in the surface layer, younger age groups keep near the thermocline, and older age groups close to the bottom (Ojaveer \& Kalejs, 1974).

Before spawning, herring feeds mostly on zooplankton (Eurytemora affinis, Acartia spp., Temora longicornis, Pseudocalanus elongatus, Limnocalanus grimaldi, Mesocyclops leuckarti). Nektobenthic organisms are also represented in its diet, but they are consumed by fish over $14 \mathrm{~cm}$ in length, and their importance varies with years.

In May-June herring feeding is affected by the reproduction cycle. Feeding intensity decreases with the increase in gonad weight. The fish migrate from the depth of 50-70 $\mathrm{m}$ at wintering sites to the depths $0.20-20 \mathrm{~m}$ at the spawning grounds. As a rule no food is taken in spawning aggregations (Telegin, 1971; Oulasvirta et al., 1983; Raid \& Lankov, 1984; Raid, 1985).

Spawning is followed by an active period of recovering, when herring starts to feed again. The main food is zooplankton, mostly the copepods Eurytemora and Acartia. In some years, depending on the conditions and the size of herring, the food may also contain nektobenthos. In August-September, the proportion of the cladocerans Bosmina coregoni maritima, Pleopsis polyphemoides, and Evadne nordmanni increases.

Differences in the feeding of herring between the western and eastern parts of the Gulf become evident; these are mainly due to the different distribution of food organisms. Eurytemora and Acartia, which are euryhaline species (Ackefors, 1969), form a part of the diet of herring throughout the whole Gulf of Finland. The cold-water marine species Pseudocalanus and Temora occur abundantly in the food of herring in the western part of the Gulf. Limnocalanus usually accounts for 2-8\% in the food of larger herring $(14-20 \mathrm{~cm})$. Bosmina, Pleopsis, and Evadne are characteristically present in both western and eastern parts of the Gulf. In summer the proportion of cladocerans and rotifers in the zooplankton is higher in the eastern part of the Gulf (Lumberg \& Ojaveer, 1991). Depending on the year, the same trend may be observed in the feeding of herring. From September-October, the share of mysids and other nektobenthic organisms increases in the diet of herring.

In autumn the water temperature drops and the feeding intensity of fish decreases. While in spring and autumn the feeding intensity of herring is controlled by the physiological state and in summer by the abundance of food, then in winter the main limiting factor is temperature (Davidyuk, 1983).

Wintering conditions also control the abundance of herring through the mortality of young fish (Ojaveer et al., 1976). In the eastern, shallow-water part of the Gulf of Finland, the water cools down more rapidly, and there the wintering aggregations of herring form earlier. In the homohaline layer fish winter at much lower temperatures than they do in the regions where the halocline and the 
heterohaline water layer are present. In the eastern part of the Gulf of Finland fish may winter at a depth of about $20 \mathrm{~m}$, where the water temperature is $0-3^{\circ} \mathrm{C}$ (Ojaveer, 1988). In the Baltic Proper and in the Gulf of Finland the wintering aggregations stay at a depth of $60-120 \mathrm{~m}$ during the daytime, where the water temperature is $2-6^{\circ} \mathrm{C}$. This depth is the lower limit of the homohaline water layer or the upper limit of the heterohaline layer. The lower boundary of the aggregation is higher than the 1-1.5 $\mathrm{mL} \mathrm{L}^{-1}$ oxygen isoline (Ojaveer et al., 1976; Ojaveer, 1988). The largest wintering aggregations usually form in the area of the coastal slope, where the mixing of homo- and heterohaline water layers promotes formation of a layer with favourable conditions. The vertical extent of the layer depends on the severity of the winter. As to the wintering conditions, the herring in the western part of the gulf is something intermediate between the sea and the gulf herring. It winters in the narrow water layer close to the halocline where the temperature is higher and the oxygen content lower than in the homohaline layer (Ojaveer, 1988).

Depending on the location of fish aggregations in winter and the water temperature, the feeding intensity of herring decreases and at temperatures below $2{ }^{\circ} \mathrm{C}$ the fish do not feed any more (Nikolaev, 1956; Yanchenko, 1980). In the eastern Gulf of Finland the fasting period may last from the second half of October up to the middle of May (Bityukov, 1961).

Taking into consideration both wintering and spawning periods, the mean length of the feeding period of the herring in the Gulf of Finland is about 270 days (Ostov, 1971; Smirnov, 1971).

\section{Long-term changes}

Changes in the environmental conditions are triggered by changes in climatic conditions. In the Baltic Sea the changes associate, first of all, with salinity. Salinity is influenced by water exchange between the Baltic and the North Sea. There was a long period of high salinity, which came to an end after the strong inflow of saline water in 1977 (Matthäus \& Franck, 1992; Møller \& Hansen, 1994). Simultaneously with the interruption of the high-salinity water inflow, the influx of fresh river water into the Gulf of Finland increased in 1977-78 (Lumberg \& Ojaveer, 1991). The decline in salinity and rather intensive vertical mixing of water layers led to changes in the species composition of the zooplankton and caused a decrease in the abundance of some invertebrate species important in herring diet.

During the recent 30 years, the abundance of the zooplankton was below its average value at the beginning of the 1970s and higher than the average in 197482. In 1983 a stagnation period started. The proportion of marine species in the zooplankton decreased and the total abundance and biomass of the zooplankton were at their lowest. This period lasted up to 1991 (Ojaveer et al., 1998). The reduction in the abundance of the marine species Pseudocalanus elongatus was in good correlation with the trend of salinity decrease. On the other hand, due to high water temperatures in summer, the abundance of the cladocerans Bosmina and rotifer Synchaeta spp. increased rapidly (Flinkman et al., 1998). 
At the end of the 1980s, the stratification of the water column weakened due to strong mixing of water masses. This resulted in the dispersion of both planktonic and nektobenthic food organisms and the diminution of their availability for herring.

As the feeding conditions in the Gulf of Finland deteriorated, the importance of feeding migrations of herring from the Gulf into the Baltic Proper increased in the second half of the 1980s (Parmanne, 1980; Lumberg \& Ojaveer, 1991; Parmanne et al., 1994; Raid, 1994).

In October-November the share of nektobenthos increases in the annual feeding cycle of herring. However, at the end of the 1980s this phenomenon was less expressed. The shortage of nektobenthic food was compensated by zooplankton. Since the energy content of zooplankton $\left(2.85 \mathrm{~kJ} \mathrm{~g}^{-1}\right.$; see Laurence, 1976) is lower than that of mysids (2.98-3.72 $\mathrm{kJ} \mathrm{g}^{-1}$; see Hakala, 1979) and amphipods $\left(3.98 \mathrm{~kJ} \mathrm{~g}^{-1}\right.$; Hill et al., 1992) in autumn, the energetical profit of feeding proved lower.

Arrhenius \& Hansson (1993) reached the same conclusion comparing in their theoretical calculations the efficiency of the ordinary mixed food of herring (zooplankton-Mysidae-Amphipoda) with zooplankton. They found that the growth of herring taking only zooplankton was $15 \%$ lower in the age groups 4-6 and $20 \%$ lower in the age group 8 .

The changes in the composition and the decrease in the abundance of important prey species were clearly reflected in herring feeding. The number of non-feeding herring with empty stomachs reached the spring and autumn maximums (80$90 \%$ ) in 1988-92. The summer maximum (60\%) was observed a couple of years earlier. Thus, in the years mentioned the feeding activity decreased substantially in the spring and autumn periods (Fig. 4). Also the food spectrum impoverished during the periods of the lowest salinity: in April 1988-90 zooplankton formed 90\% and in November-December 1991-92 100\% of the diet of herring (Lankov \& Raid, 1997). In summer, after spawning, the proportion of nektobenthos showed a slight decrease in 1987-88, but without any evident trend. Traditionally, zooplankton forms the basic part of herring's food (Fig. 5).

In the Baltic Sea cod is the main species controlling the abundance of pelagic fishes in the food web. This is most clearly revealed in the Baltic Proper, which is its basic distribution area. The cod population of the eastern Baltic extends to the western Gulf of Finland only during the high-salinity periods when the abundance of cod is extremely high (Ojaveer et al., 1985). However, as in the coastal waters of Hiiumaa Island and in the Gulf of Finland the abundance of cod is low even in the years of its favourable stock size, the pressure through the food web on herring and sprat is considerably less than in the southern areas. Because of the lowsalinity stagnation period, which started in the 1980s (Bagge et al., 1994; Møller $\&$ Hansen, 1994; Sparholt, 1994), the abundance of cod and its predation pressure on pelagic fishes have been at their lowest level in the Baltic Sea since the 1990s.

Food abundance and feeding conditions influence directly herring's growth rate. As an active pelagic fish, herring spends most of its energy on metabolic processes 


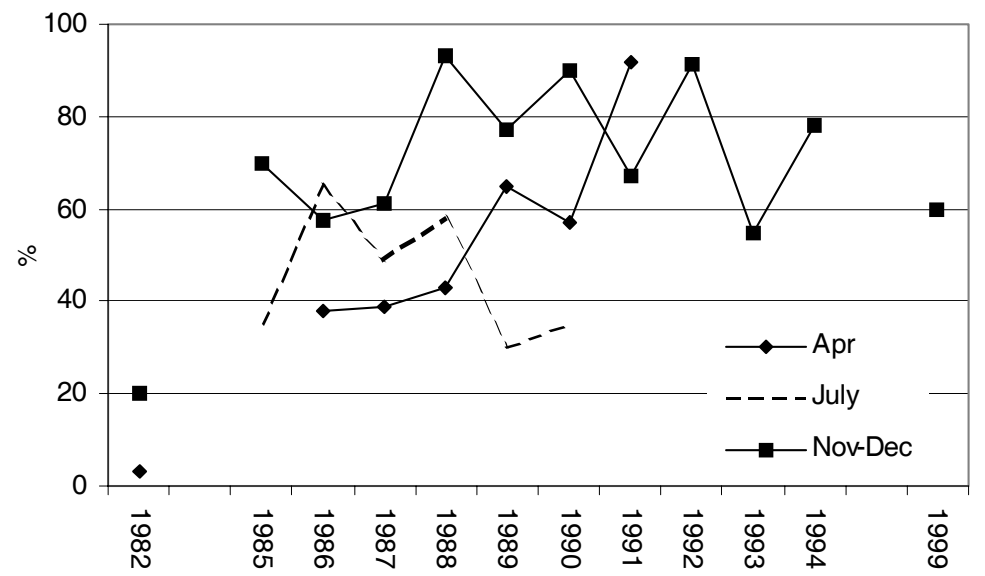

Fig. 4. Percentage of herring with empty stomachs in the Gulf of Finland in April 1982-91, July 1985-90, and November-December 1982-99.

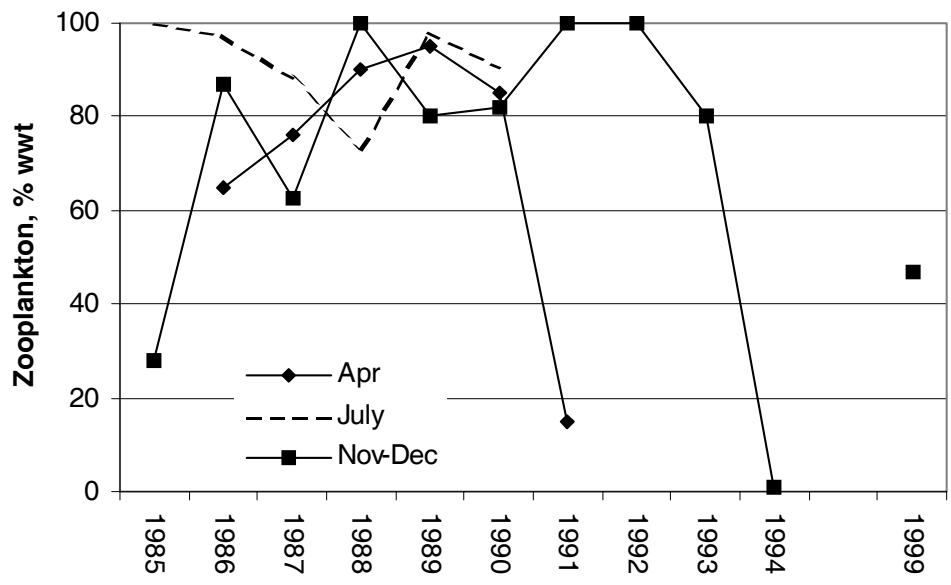

Fig. 5. Share of zooplankton in herring stomachs in the Gulf of Finland in April 1985-91, July 1985-90, and November-December 1985-99.

(74-77\% in $1970-98$ ) and only $2-4 \%$ on growth and $2-3 \%$ on reproduction. Thus, the feeding period from early spring to late autumn is vitally important for herring to accumulate reserves and energy for producing gonadal products and maintaining living ability for wintering and spawning periods. In the northernmost Baltic Sea, like in the Gulf of Finland, the growth of herring is slower than in the other areas of this sea because of severe environmental conditions, resulting in a short vegetation period (Ojaveer, 1981). In the 1950s-60s, the growth of herring 


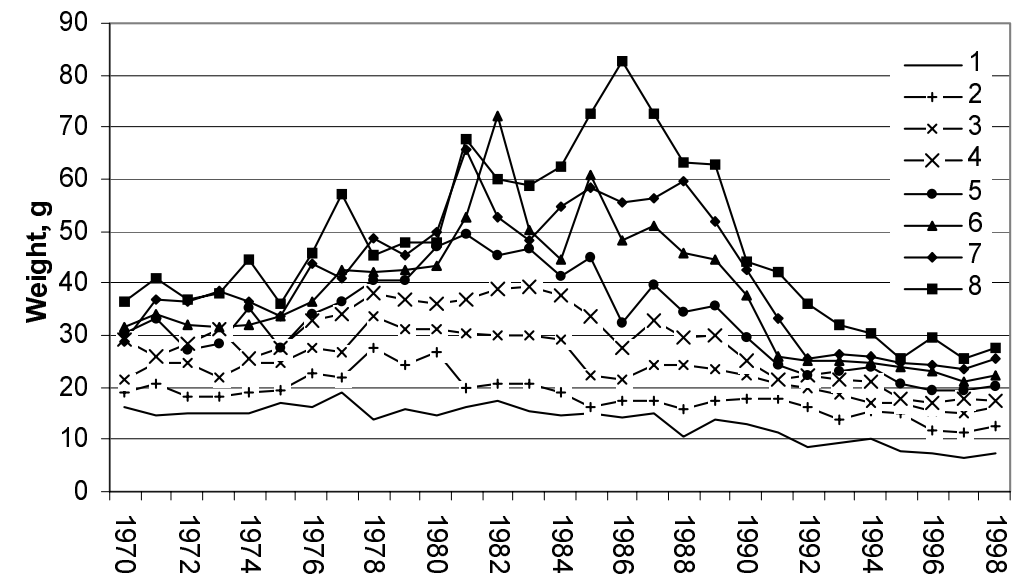

Fig. 6. Mean weight at age of herring in age groups 1-8 in the Gulf of Finland.

did not exhibit any notable trend (Ojaveer \& Rannak, 1980). Since the 1970s, the mean weight at age of Baltic herring started to rise gradually. The highest value was recorded in the second half of the 1970s for the age groups 1-3 and in 198286 for the age groups 4-8 (Fig. 6). The second half of the 1980s witnessed a drastic decrease in the mean weight of herring in the Gulf of Finland. Since 1996, it has stabilized, but at a lower level (ca $10 \mathrm{~g}$ for the age groups 5-8) than at the beginning of the 1970s. A decrease in the mean weight at age of Baltic sprat can be observed since the beginning of the 1990s (Aps, 1992; Raid \& Lankov, 1995; Kaljuste, 1999).

\section{Changes after the 1993 inflow}

The trend of salinity reduction in the Gulf of Finland has reversed since 1993 (during 1992-98 it rose 0.5 psu). The same is valid for the Gulf of Riga: in 1994-97 the salt content rose $0.8 \mathrm{psu}$ in the near-bottom water layer (Ojaveer et al., 1999). This is probably connected with a short-term inflow from the Danish Sound in January 1993 (Håkansson et al., 1993; Matthäus et al., 1994). After this event the proportion of herring's empty stomachs diminished. The share of energetically favourable nektobenthos rose in its diet. These changes indicate improved feeding conditions.

\section{Abundance, biomass, and annual food consumption dynamics of the Baltic herring}

The calculations of mean weights, abundance, and biomass are based on the data from stock assessment by ICES (Anon., 1994, 1997, 1999). During 1970-98 
the abundance of herring in the Gulf of Finland ranged from 4647 to $16301 \times 10^{6}$ individuals or $0.16-0.55$ ind $^{-2}$, and the biomass from $130 \times 10^{3}$ tonnes to $264 \times 10^{3}$ tonnes or $4.41-8.97 \mathrm{~g} \mathrm{~m}^{-2}$ (Fig. 7). In the late 1970s the biomass and abundance of herring started to increase, and the maximum biomass was reached in the second half of the 1980s. At the beginning of the 1990s the abundance continued to grow, but at the end of the decade the growth slowed down. A small increase in the biomass was also observed, but it was much less than in the 1980s, and at the end of the 1990s the biomass of herring was comparatively low in the Gulf of Finland.

In calculating herring's annual consumption, it was taken into account that there are no precise data available for all the years on the zooplankton-nektobenthos ratio. In the final calculations the summary consumption of herring is presented. According to 1986-90 data, zooplankton (wet weight) made up 74.1\%, mysids $18.2 \%$, amphipods $5.5 \%$, juvenile fish $1.8 \%$, and other food items $0.4 \%$ (Raid \& Lankov, 1995).

In calculating herring's ration, the abundance and composition of the stock, mean weights at age, the composition of food, and water temperature were taken into consideration. To the ration obtained for herring in the age groups 1-10, 45\% of larval and 0-group fish consumption was added (Rudstam, 1988; Arrhenius $\&$ Hansson, 1993). Annual consumption fluctuates within a wide range - from 60 to $130 \mathrm{~g} \mathrm{~m}^{-2}$ wwt (Fig. 8).

The greatest pressure on food organisms by herring occurred at the end of the 1980s, when the abundance of the zooplankton was at its lowest since the 1970s. By the end of the 1990s, the annual consumption had decreased to the late1970s level (60-70 $\left.\mathrm{g} \mathrm{m}^{-2} \mathrm{wwt}\right)$.

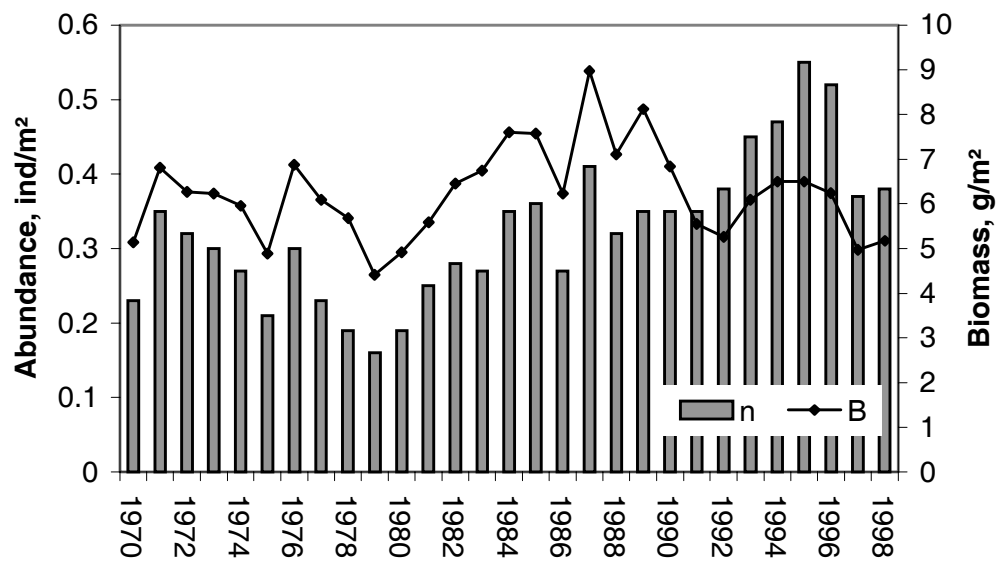

Fig. 7. Abundance (n) and biomass (B) of herring in the Gulf of Finland in 1970-98. 


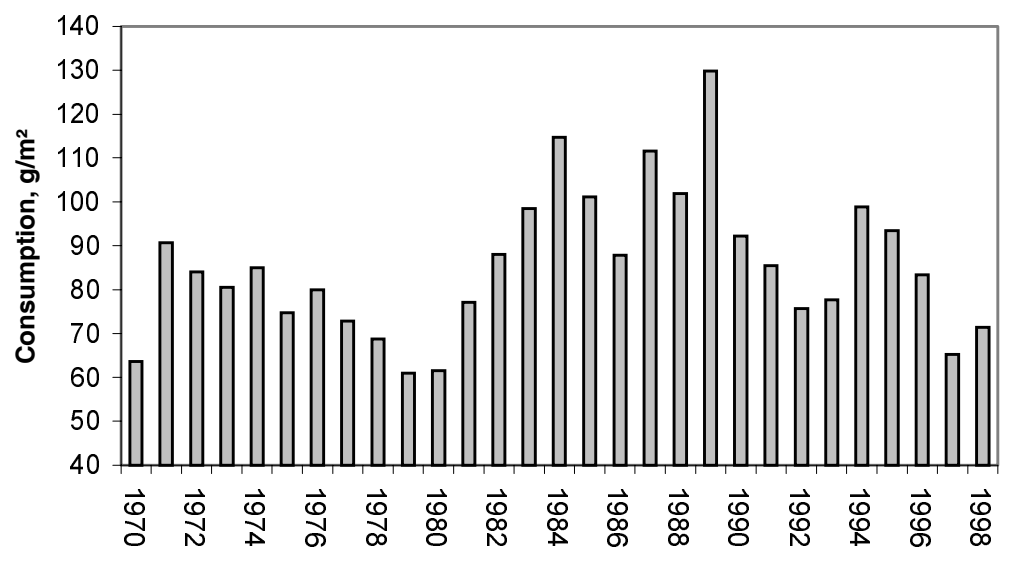

Fig. 8. Annual food consumption of herring in the Gulf of Finland in 1970-98.

A characteristic feature of the 1970s and the first half of the 1980s was significant fluctuations of the annual metabolic rate, which varied from $74.4 \%$ to $76.5 \%$, and of the growth rate, making up $1.6 \%$ to $3.5 \%$ of the annual ration. In the second half of the 1980s and in the 1990s the amplitudes of metabolic and growth rates were restricted compared to the previous period $(74.7-75.9 \%$ and $2.3-2.9 \%$, respectively).

The proportion of energy released for spawning made up $1.7-2.4 \%$ of the annual ration in the $1970 \mathrm{~s}-80 \mathrm{~s}$. In the $1990 \mathrm{~s}$ its proportion rose, forming from $2.0 \%$ to $2.7 \%$ of the ration. Simultaneously the annual metabolic rate decreased from $75.9 \%$ to $74.8 \%$.

\section{CONCLUSIONS}

Alteration of hydrological conditions, mainly the decline in the salinity, has changed the feeding conditions of herring in the Baltic Sea, including the Gulf of Finland. In the late 1980s-early 1990s, the number of non-feeding herring and the share of zooplankton in the food increased, especially in the spring and autumn periods. This together with the increase in the abundance of herring (and sprat) and the reduction of the abundance of cod has affected the growth of herring. A drastic decrease of the mean weights of herring age groups, which started in the second half of the 1980s, ceased in the second half of the 1990s and stabilized at the level about $10 \mathrm{~g}$ lower than at the beginning of the 1970s.

In 1970-98 the annual consumption of the Baltic herring was $60-130 \mathrm{~g} \mathrm{~m}^{-2}$. The Baltic herring exerted the highest pressure on the food resources at the end of the 1980s. 


\section{REFERENCES}

Ackefors, H. 1969. Ecological zooplankton investigations in the Baltic Proper 1963-1965. Rep. Inst. Nar. Res. Fish. Board Swed. Ser. Biol., 18.

Aneer, G. 1975a. Composition of food of the Baltic herring (Clupea harengus v. membras L.), fourhorn sculpin (Myoxocephalus quadricornis L.) and eelpout (Zoarces viviparus L.) from deep soft bottom trawling in the Askö-Landsort area during two consecutive years. Meretutkimuslaitiksen Julk. Havskorskningsinst. Skr., 239, 146-154.

Aneer, G. 1975b. A two year study of the Baltic herring in the Askö-Landsort area, 1970-72. Contrib. Askö Lab., Univ. Stockholm, $\mathbf{8}$.

Aneer, G. 1979. On the ecology of the Baltic herring studies on spawning areas, larval stages, locomotory activity pattern, respiration, together with estimates of production and energy budgets. PhD thesis, University of Stockholm.

Aneer, G. 1980. Estimates of feeding pressure on pelagic and benthic organisms by Baltic herring (Clupea harengus v. membras L.). Ophelia, 1, 265-275.

Anon. 1994. Report of the Working Group on the Assessment of the Pelagic Stocks in the Baltic. ICES CM 1994/Assess. 18.

Anon. 1995. Report of the Working Group on the Assessment of Demersal and Pelagic Stocks in the Baltic. ICES CM 1995/Assess. 18.

Anon. 1997. Report of the Baltic Fisheries Assessment Working Group. ICES CM 1997/Assess. 12.

Anon. 1999. Report of the Baltic Fisheries Assessment Working Group. ICES CM 1999/Assess. 15.

Aps, R. 1992. Growth of sprat in the Northern Baltic. ICES CM 1992/J:44.

Arrhenius, F. \& Hansson, S. 1993. Food composition of larval, young and adult herring and sprat in the Baltic Sea. Mar. Ecol. Prog. Ser., 96, 125-137.

Arrhenius, F. \& Hansson, S. 1995. Growth and seasonal changes in energy content of young Baltic Sea herring (Clupea harengus L.). ICES CM 1995/J:4.

Astok, V. \& Mardiste, H. 1995. Nüüdismeri. In Eesti. Loodus (Raukas, A., ed.), pp. 228-237. Valgus, Tallinn.

Bagge, O., Thurov, F., Steffenson, E. \& Bay, J. 1994. The Baltic cod. Dana, 10, 1-28.

Bityukov, E. P. 1961. Feeding of the Baltic herring in the eastern part of the Gulf of Finland. Vopr. ikhtiol., 4(21), 725-736 (in Russian).

Chekunova, V. I. 1979. Energetic requirements of the Baltic herring. Vopr. ikhtiol., 19(4), 710-717 (in Russian).

Chekunova, V. I. \& Naumov, A. G. 1977. Metabolism of the Falkland sprat (Sprattus fugensis). Vopr. ikhtiol., 17(2), 338-344 (in Russian).

Davidyuk, A. P. 1983. Feeding of the Baltic herring in 1976-1980. Rybokhoz. issled. bass. Balt. morya, 18, 31-34 (in Russian).

Davidyuk, A. P. 1996. Herring and sprat feeding in 1994 and 1995 in the eastern Baltic. ICES CM 1996/J:24.

Feldman, V. N., Patokina, F. A. \& Kalinina, N. A. 2001. Recent changes in diet composition and daily food intake of the Baltic herring in the Gdansk basin of the Baltic Sea. ICES CM 2001/U:02.

Flinkman, J. 1999. Interactions between plankton and planktivores of the northern Baltic Sea: selective predation and predation avoidance. Walter and Andrée de Nottbeck Found. Sci. Rep., 18.

Flinkmann, J., Vuorinen, I. \& Aro, E. 1992. Planktivorous Baltic herring (Clupea harengus L.) prey selectivity on reproducting copepods and cladocerans. Can. J. Fish. Aquat. Sci., 49, 73-77.

Flinkman, J., Aro, E., Vuorinen, I. \& Viitasalo, M. 1998. Changes in northern Baltic zooplankton and herring nutrition from 1980-s to 1990-s: top-down and bottom-up process at work. Mar. Ecol. Prog. Ser., 165, 127-136.

Green, J. R. 1978. Theoretical food rations of Gulf of Maine and Georges Bank herring stocks. ICES CM 1978/L:39. 
Hakala, J. 1979. Seasonal variation in the carbon and energy contents and assimilation of a Mysis relicta population in Pääjärvi, southern Finland. Ann. Zool. Fenn., 16, 129-137.

Håkansson, B. G., Broman, B. \& Dahlin, H. 1993. The flow of water and salt in the Sound during the Baltic major inflow event in January 1993. ICES CM 1993/C:57.

HELCOM. 1996. Third periodic assessment of the state of marine environment of the Baltic Sea, 1989-93. Baltic Sea Environ. Proc., 64B, Helsinki.

Hill, C., Quigely, M. A., Cavaretto, J. F. \& Gordon, W. 1992. Seasonal changes in lipid content and composition in the benthic amphipods Monoporeia affinis and Pontoporeia femorata. Limnol. Oceanogr., 37, 1280-1289.

Jespersen, P. 1936. The food of the herring in the waters round Bornholm. Medd. Kommn. Dan. Fisk. Havunders. Ser. Plankton, $\mathbf{3}$.

Kaljuste, O. 1999. Changes in the growth and stock structure of Baltic sprat (Sprattus sprattus balticus) in the Gulf of Finland in 1986-97. Proc. Estonian Acad. Sci. Biol. Ecol., 48, 296309.

Kostrichkina, E. M. \& Starodub, M. L. 1980. Feeding and trophical relations of the Baltic herring and sprat. In Ecosystems of the Baltic States, pp. 332-349. Gdynia (in Russian).

Lankov, A. 1986. The food of young Baltic herring (Clupea harengus membras L.) in the Gulf of Finland. ICES CM 1986/J:4.

Lankov, A. \& Raid, T. 1997. Long-term changes in the feeding of the Baltic herring and sprat in the Gulf of Finland. In Proceedings of the 14th Baltic Marine Biologists Symposium (Ojaveer, E., ed.), pp. 130-138. Estonian Academy Publishers, Tallinn.

Lasker, R. 1973. Utilization of zooplankton energy by a Pacific sardine population in the California Current. In Marine Food Changes (Steele, J. H., ed.), pp. 265-284. Oliver and Boyd, Edinburgh.

Laurence, G. C. 1976. Caloric content of some North Atlantic calanoid copepods. Fish Bull. US, 78, 218-220.

Lumberg, A. \& Ojaveer, E. 1991. On the environment and zooplankton dynamics in the Gulf of Finland in 1961-1990. Proc. Estonian. Acad. Sci. Ecol., 1, 131-140.

Matthäus, W. \& Franck, H. 1992. Characteristics of major inflows - a statistical analysis. Cont. Shelf. Res., 12(12), 1375-1400.

Matthäus, W., Nehring, D. \& Nausch, G. 1994. Effects of the inflow of salt-rich water during 1993 and in early 1994 in the Central Baltic Sea. ICES CM 1994/Q:3.

Melnichuk, G. L. 1980. Methodological Recommendations Concerning the Use of Methods for Feeding Studies and Calculations on the Fish Production by Feeding Base in Natural Conditions. GosNIORHk, Leningrad (in Russian).

Møller, J. S. \& Hansen, J. S. 1994. Hydrographic processes and changes in the Baltic Sea. Dana, 10, 87-104.

Nikolaev, I. I. 1956. Feeding conditions and growth of the Baltic herring. Tr. BaltNIRO, 2, 115-132 (in Russian).

Ojaveer, E. 1981. Influence of temperature, salinity and reproductive mixing of Baltic herring groups on its embryonal development. Rapp. P.-v. Reun. Cons. Int. Explor. Mer., 178, 409415.

Ojaveer, E. A. 1988. The Baltic Herrings. Agropromizdat, Moscow (in Russian).

Ojaveer, E. \& Elken, J. 1997. On regional subunits in the ecosystem of the Baltic Sea. In Proceedings of the 14th Baltic Marine Biologists Symposium (Ojaveer, E., ed.), pp. 130-138. Estonian Academy Publishers, Tallinn.

Ojaveer, E. A. \& Kalejs, M. V. 1974. On some oceanographic preconditions of distribution of the Baltic Sea pelagic fishes. Okeanologiya, 14(3), 544-554 (in Russian).

Ojaveer, E. \& Rannak, L. 1980. Dynamics of some parameters of herring populations in the Northeastern Baltic in 1948-1979. ICES CM 1980/H:22.

Ojaveer, E. A. \& Veldre, I. R. 1976. Changes of fish resources in the Gulf of Finland during the last 10 years. Rybokhoz. issled. bass. Balt. morya., 12, 114-120 (in Russian). 
Ojaveer, E. A., Kalejs, M. V. \& Veldre, I. R. 1976. Distribution of the Baltic herring and sprat depending on wintering conditions in northern and eastern parts of the Baltic. Fisch.Forsch., 14(1), 23-25 (in Russian).

Ojaveer, E., Kalejs, M., Aps, R., Lablaika, I. \& Vitins, M. 1985. The impact of recent environmental changes on the main commercial fish stocks in the Gulf of Finland. Finn. Fish. Res., 6.

Ojaveer, E., Lumberg, A. \& Ojaveer, H. 1998. Highlights of zooplankton dynamics in Estonian waters (Baltic Sea). ICES J. Mar. Sci., 55, 748-755.

Ojaveer, H., Lankov, A., Eero, M., Kotta, J., Kotta, I. \& Lumberg, A. 1999. Changes in the ecosystem of the Gulf of Riga from the 1970s to the 1990s. ICES J. Mar. Sci., 56, 33-40.

Ostov, I. M. 1971. Characteristics of the hydrological and hydrochemical regime in the Gulf of Finland as a base of fisheries. Izv. GosNIORHk, 76, 18-45 (in Russian).

Oulasvirta, P., Rissanen, J. \& Parmanne, R. 1983. Spawning of Baltic herring (Clupea harengus membras L.) in the western part of the Gulf of Finland. ICES CM/J:24.

Parmanne, R. 1980. Growth, morphological variation and migrations of herring (Clupea harengus L.) in the Northeastern Baltic Sea. Finn. Fish. Res., 10.

Parmanne, R., Rechlin, O. \& Sjöstrand, B. 1994. Status and future of herring and sprat stocks in the Baltic Sea. Dana, 10, 29-59.

Perttilä, M., Tulkki, P. \& Pietikäinen, S. 1980. Mean values and trends of hydrographical and chemical properties in the Gulf of Finland 1962-1978. Finn. Mar. Res., 247, 38-50.

Popiel, J. 1951. Feeding and food of the herring (Clupea harengus L.) in the Gulf of Gdansk and in the adjoining waters. Pr. Morsk. Inst. Ryb. Gdyni, 6, 29-56.

Raid, T. 1985. The reproduction areas and ecology of Baltic herring in the early stages of development found in the Soviet zone of the Gulf of Finland. Finn. Fish. Res., 6, 20-34.

Raid, T. 1994. Structure of Estonian herring catches in the Gulf of Finland. ICES CM 1994/J:21.

Raid, T. \& Lankov, A. 1984. Räime noorjärkude jaotumisest ja toitumisest. Abiks Kalurile, 1, 2-11.

Raid, T. \& Lankov, A. 1991. On growth of the Baltic herring on the Gulf of Finland. ICES CM 1991/J:11.

Raid, T. \& Lankov, A. 1995. Recent changes in the growth and feeding of Baltic herring and sprat in the northeastern Baltic Sea. Proc. Estonian. Acad. Sci. Ecol., 5, 38-55.

Rannak, L. A. 1970. Fecundity of the Gulf of Finland herring. Tr. BaltNIIRHka, 4, 228-255 (in Russian).

Ricker, W. 1973. Linear regression in fishery and fishery research. J. Fish. Res. Board Can., 30, 409-434.

Rudstam, L. G. 1988. Exploring the dynamics of herring consumption in the Baltic: applications of an energetics model of fish growth. Kiel. Meeresforsch. Sonderh., 6, 312-322.

Rudstam, L. G., Hansson, S., Johansson, S. \& Larsson, U. 1992. Dynamics of planktivory in a coastal area of the northern Baltic Sea. Mar. Ecol. Prog. Ser., 80, 159-173.

Rudstam, L. G., Aneer, G. \& Hilden, M. 1994. Top-down control in the pelagic Baltic ecosystem. Dana, 10, 105-129.

Sjöblom, V. 1961. Wanderungen des Strömlings (Clupea harengus L.) in einigen Schären- und Hochseegebieten der Nördlichen Ostsee. Merentutkimuslait. Julk./Havsforskninginst., 199, $166-182$.

Smirnov, A. N. 1971. Baltic herring in the Gulf of Finland. Izv. GosNIORHk, 76, 3-17 (in Russian).

Sparholt, H. 1994. Fish species interactions in the Baltic Sea. Dana, 10, 131-162.

Szypuła, J. \& Załachowski, W. 1984. Duration of food evacuation in herring, Clupea harengus L., and sprat, Sprattus sprattus L. Acta Ichtyol. Piscat., 14(1-2), 93-104.

Szypuła, J., Grygiel, W. \& Wyszynski, M. 1997. Feeding of Baltic herring and sprat in the period 1986-1996 in relation to their state and biomass. Bull. Sea Fish. Inst., 3(142), 73-83.

Sushkina, A. P. 1954. Feeding of the Baltic herring in the Baltic Sea and Gulf of Riga. Tr. VNIRO, 26, 118-136 (in Russian).

Telegin, K. F. 1971. Distribution of the Baltic herring in the eastern part of the Gulf of Finland. Izv. GosNIORHk, 76, 91-99 (in Russian). 
Trauberga, E. T. 1979. Feeding interactions of the Baltic herring (Clupea harengus membras L.) and sand goby (Pomatoschistus minutus L.) and their importance in the formation of herring generations in the Gulf of Riga. PhD thesis abstract. Sevastopol (in Russian).

Winberg, G. G. 1956. Rates of Metabolism and Food Requirements of Fish. Izd. BGU, Minsk (in Russian).

Winberg, G. G. 1966. Rates of growth and metabolism of animals. Usp. sovrem. biol., 61(2), 274293 (in Russian).

Winberg, G. G. 1970. Energy flow in aquatic ecological system. Pol. Arch. Hydrobiol., 17(30), 11-19.

Yanchenko, N. N. 1980. The feeding of young Baltic herring in Vistula Bay in winter. Ann. Biol., 35, 191-192.

\section{Räime toitumine Soome lahes 1970.-1990. aastatel}

\section{Ain Lankov ja Henn Kukk}

Tulenevalt muutusest hüdroloogilistes tingimustes, eelkõige soolsuse vähenemisest, on muutunud räime toitumistingimused Läänemeres, sealhulgas ka Soome lahes. 1980-ndate lõpus ja 1990-ndate alguses suurenes mittetoituvate räimede hulk ja zooplanktoni osatähtsus toidus, seda eriti kevad- ja sügisperioodil. Eeltoodu koos räime (ja kilu) arvukuse suurenemisega ning tursa arvukuse vähenemisega on avaldanud mõju räime juurdekasvule. 1980-ndate teisel poolel alanud drastiline räime vanuserühmade keskmiste kaalude langus on 1990-ndate teisel poolel peatunud ja stabiliseerunud, kuid räime kaal on $\sim 10 \mathrm{~g}$ väiksem kui 1970-ndate alguses. 1970.-1998. aastal oli räime toidutarve aastas $60-130 \mathrm{~g} / \mathrm{m}^{2}$, suurim surve toidubaasile ilmnes 1980-ndate lõpus. 